\title{
Sales compensation plans - One size does not fit all
}

Received (in revised form): 4th February, 2005

\section{Lynette J. Ryals}

is a senior lecturer at Cranfield School of Management, and Director of Cranfield's Key Account Management Best Practice Research Club. Her career has also encompassed many years in consultancy and fund management. She is a registered representative of the London Stock Exchange.

\section{Beth Rogers}

manages the MA Sales Management at Portsmouth Business School. She chairs the Sales Steering Group of the Marketing and Sales Standards Setting Body (MSSSB) and is Research Director for the Institute of Sales and Marketing Management (ISMM). Her career also includes many years in the IT industry.

Abstract This paper considers the state of variable pay compensation plans for sales people in business-to-business markets and, in particular, reviews proposed methods for rewarding key account managers. The authors suggest that, rather than have one instrument to determine rewards for all professionals involved in selling, the reward mechanism should be determined by the type of prospect or customer and the level of skill involved. The authors argue that only companies that have a portfolio approach to sales pay, with pay reflecting the type of customer and the skills required to manage the relationship, will achieve appropriate motivation and productivity.

Lynette J. Ryals

Cranfield School of Management, Cranfield, Bedfordshire MK43 OAL, UK.

Tel: +44 (0) 1234751122 ; e-mail: Lynette.ryals@ cranfield.ac.uk

\section{INTRODUCTION}

As long ago as 1999 in an article considering the compensation plans for global account managers, Dan Weilbaker argued that 'as the role of the salesperson has changed, compensation hasn't'. He observed that a significant proportion of pay was still focused on sales volume, although the sales process was often no longer individual but achieved by the account team. ${ }^{1}$ In 2004 variable pay based on sales volume was still alive and well in the sales profession. The 2004 Sales Compensation Trends Survey sponsored by The Alexander Group found that, of 260 US companies participating (each had at least 20 full-time salespeople), only 8 per cent of respondents did not use annual quotas to reward their salespeople. ${ }^{2}$ This is a paradox: transactional reward structures still seem to be mainstream despite the increasing number of salespeople migrating to account management roles that require long-term results and a team approach.

The number of key account managers is increasing. By 1995, 35 per cent of US manufacturing firms and 30 per cent of service companies had adopted a single sourcing purchasing strategy ${ }^{3}$ and a similar trend was apparent in Europe. ${ }^{4}$ The account manager who nurtures 100 per cent of a customer's needs for his or 
her company's product category has to focus on quality, the customer's business needs and the processes and communications needed to support the business relationship. In some cases, selling may be a very small part of the job, although it is still critical. Key account managers are standard-bearers for their company; they are the relationship builder fronting a highly talented band of colleagues. ${ }^{5}$ Best practice companies that are adopting longer-term buyer-seller relationships include Ford, Xerox, GE, GM, Honda (US) and Honeywell. ${ }^{6}$ Key account managers do bear the brunt of managing complex and non-programmable situations that occur in supplier-customer relationships, but they could not meet the customer's needs, solve problems and facilitate further sales without their team. How these talented, vital relationship managers are rewarded and motivated is an increasingly important issue.

\section{DOES MONEY MOTIVATE THE KEY ACCOUNT MANAGER?}

Human performance is still the most variable factor in the efficient functioning of a company with its customers ${ }^{7}$ and this is particularly true in business-to-business relationships. Most commentators agree that performance relies on a salesperson's knowledge, skills and motivation, but there is no consensus about the role of money as a motivator. Custom and practice in companies seems to be based on the assumption that money is the key motivator for salespeople, and is in itself a measure of performance and a way of exercising power. ${ }^{8}$ Sixty-seven per cent of UK companies use a combination of salary and commission because they perceive that incentives linked to performance outcomes can stimulate effort. ${ }^{9}$ Bartol notes that rewards tied to outcomes do have a positive motivating effect, with the proviso: where rewards are perceived to be fair. ${ }^{10}$ For example, in the electronic components industry, 40 per cent of salespeople have reward systems that contain a variable element. Typically, the overall rewards are higher, the higher the proportion of variable pay (because commission is intrinsically more risky than salary). The electronics components salespeople with the higher variable elements tended to display higher commitment to the firm. ${ }^{11}$ Liberty Courier Inc in the USA found that pure salary packages led to high sales force turnover; after changing to a variable pay system, sales jumped 130 per cent in the first year. $^{12}$

Variable pay is culturally ingrained in sales custom and practice. Researchers have, however, found that it presents sales managers with many substantial and sometimes expensive problems. There are anomalies that undermine commonly accepted assumptions. For example, salespeople do not really like high fluctuations in income ${ }^{13}$ and become quickly demoralised by a bad month. For example, a domestic telecoms equipment company found that its field salespeople, who were paid on 100 per cent commission, tended to leave after a single bad month, even if their average performance was good. This was damaging to the company, which eventually had to switch back to a system that rewarded recent performance. ${ }^{14}$ Douglas Laboratories, based in Pittsburgh, recognised these issues and designed a reward system that enabled top salespeople to sell more but on a steady basis. ${ }^{15}$

Contrary to the assumption of causation between reward and satisfaction, the most highly rewarded salespeople are often the most dissatisfied. ${ }^{16}$ Moreover, competitive pay structures create more losers than winners 
and counteract teamwork, creating strife and even unethical behaviour, including covert sabotage ${ }^{17}$ or game playing by salespeople. ${ }^{18}$ For example:

- channel stuffing: if commission is triggered by an order, the salesperson convinces the customer or channel partner to take goods 'on trial' — for an unlimited period;

- multiple booking: salespeople claim commission on existing orders in another system which he/she had little or nothing to do with, such as international transactions;

- sandbagging: where a salesperson brings forward delivery dates to raise results in a particular month or quarter. Apart from the effects on the compensation budget, such behaviour can seriously disrupt production and have knock-on costs such as overtime and over-ordering of stock. ${ }^{19} \mathrm{~A}$ variation of sandbagging can occur in multi-year agreements, ie overstatement of revenue in the early years to realise rewards sooner.

The attitude of the game players is that 'company rules are suggestions'. ${ }^{20}$ Even advocates of variable pay comment that commission is an inducement to take a short-term view.

Unfortunately, most compensation plans are not designed to preclude games and disputes. Therefore, salespeople prepared to be persistent can exploit grey areas to achieve overpayment. It is estimated that 3-5 per cent of total sales compensation paid in industry is overpayments. ${ }^{21}$ Sometimes, forms of overpayment are built into systems. For example, many companies allow special incentive funds (SPIFs), which are locally administered, without monitoring whether the local goals being rewarded are in line with corporate goals.

On the other hand, compensation plans often include a cap to ensure that salespeople do not earn more than has been budgeted. Capping is a blunt tool to limit earnings and may be resented if the salesperson has achieved really exceptional performance. Even the existence of a cap (whether or not it is triggered) can cause resentment. ${ }^{22}$

If variable pay schemes have the disadvantages noted here and may result in damage to customer relationships, why do they persist?

\section{THE PERSISTENCE OF VARIABLE PAY SYSTEMS}

Despite the inherent problems of variable pay systems, they persist. Change is inhibited by an unfortunate 'chicken and egg' situation in which managers fear that, if they change their compensation scheme and a competitor does not, good salespeople will leave and take their skills and their contacts to the opposition.

Discussion about compensation packages for salespeople often revolves around a concept of the salesperson as an 'agent'. ${ }^{23}$ Between the sales manager (the principal) and the salesperson (the agent) there is a 'contract'. The contract may specify behaviours as well as outcomes, but it has to be monitored at little cost to agent activity, and outcomes are easier to measure. When measured on outcomes, the salesperson is taking on more personal risk; therefore, it is expected that he or she demands more reward. This model is based on the assumption that the salesperson is independent and has single-handed involvement in the sale; clearly this is not the case in many key account management positions. Still worse, the concept of the salesperson as an agent has fostered perceptions of their disloyalty. ${ }^{24}$

This highly tactical approach to direct employees involved in selling treats them as equivalent to third-party channels to 
market, and therefore raises issues about the delivery of brand values. In the information and communications technology (ICT) industry, where use of resellers is widespread, manufacturers also employ account managers to act as standard-bearers looking after strategic customers.

Account managers are clearly not independent nor do they have single-handed involvement in the sale, therefore it seems logical to suggest that the 'agent' concept is not applicable and variable pay should not necessarily be a 'given' in their compensation plan.

\section{MOTIVATION AND REWARD FOR KEY ACCOUNT MANAGERS}

Cooke describes the sales compensation

plan as a simple payoff between control and motivation. ${ }^{25}$ The control element of a salesperson's pay is salary; the motivational element is commission. Fringe benefits are salary; prizes in sales competitions and similar ad hoc incentives are commission. He noted that an emphasis on salary is more important when the results of the salesperson's efforts are difficult to measure in the short term, and where the salesperson's role requires duties that do not show results in the short term. Duties such as service, contact development, information seeking, learning and planning do not show results in the short term, and they are important in key account management. It should also be considered that a number of commentators equate high levels of commission for salespeople with encouragement to take risks. Do sales managers really want key account managers to take risks with strategic customers? This dilemma was noted as long ago as 1988 in speciality retailers in a suburban shopping centre, where people doing standard selling jobs had salary-based packages whereas account managers were more likely to have a commission-based element in their reward packages. To overcome the risk issue, these stores tried to increase the supervision of their account managers; the researcher commented that it was unclear whether this reward system was truly optimal. ${ }^{26}$

Salespeople/account managers with long-term relationships with their customers place more importance on salary. Their motivators include satisfaction with doing a good job, satisfying customer needs, meeting family responsibilities and retaining their jobs. Other motivators that have been observed are recognition, promotion, training and better job content. Key account managers work without much supervision and are required to be boundary spanners between the supplier and the customer. As a result they suffer from high levels of role ambiguity. Working with one or a few accounts means that the outcomes in the short term are likely to be determined by factors which he or she cannot influence, such as market fluctuations, changes in the competitiveness of the customer's industry and short-term production pressures. Moreover, the supplier-customer relationship is operating at many points of contact and the key account manager has to spend a significant proportion of time on leading and managing within his/her own organisation.

All these factors suggest that key account managers should have a higher proportion of their take-home pay based on salary compared to the average field salesperson, although Donaldson noted in his research that only 15 per cent of account managers would prefer salary-only pay packages. A survey of 2,446 sales executives by Sales and Marketing Management (US) found that the use of cash as an incentive decreased 
14 per cent from 2002 to 2003. One respondent said that he had switched to investing in good management; another believed recognition could go further than cash. ${ }^{27}$

Research by Weilbaker suggests that, on average, key account managers would have on-target earnings composed of 75 per cent salary and 25 per cent variable pay. ${ }^{28}$ In order to design compensation plans for key account managers, he found that generally companies have 'patched' field systems, ie they have taken a scheme operating for field sales and amended it rather than designing something new. In the particular case of global account manager compensation, plans were very diverse and proceeded by trial and error.

What should the 25 per cent be based on? Since one of the observed benefits of a key account management approach is improved bottom-line profitability, ${ }^{29}$ some companies have changed from rewards based on sales volume to rewards based on account profitability. Despite the emergence of activity-based costing as an ideal, it is very difficult for companies to find systems for allocating overheads to specific accounts. For companies that have tackled the measurement issue it is apparent that rewarding account managers on the basis of profit quotas does improve profit performance. $^{30}$

\section{DESIGNING AN APPROPRIATE REWARD SYSTEM FOR KEY ACCOUNT MANAGERS}

Most companies have multiple objectives for their key accounts, of which sales volume is one. O'Connell and Marchese $^{31}$ found other objectives including:

- renewal of customer contracts;

- sales results over a number of years;
— increased share of customer spend;

- account growth;

- 360 degree feedback on management effectiveness;

— specific personal objectives.

Whatever the combination, a multiple objectives approach can be more closely tied to company goals than simple volume schemes. Sometimes this involves starting from scratch to design key account management rewards, ${ }^{32}$ perhaps following Bartol's process: compensation design, followed by goal-setting, performance evaluation and then allocation of rewards. ${ }^{33}$ Last but not least, Bartol included 'affective responses' including perceptions of justice in his process. In the case of key account managers, the challenge of fairness is wider than with field sales. Key account team members often expect rewards for their contribution to expanding business with strategic customers.

An additional complication when designing a reward scheme for key account managers is that they are usually supported by a team. The team may feel that the key account manager is not the only one who deserves bonuses. Years ago, a thank-you drink in the pub might have sufficed, but today technical, administrative and operational staff are much more aware of their importance in customer focus. Indeed, research by Sharma demonstrates that customer service contributes about twice as much to customer satisfaction perceptions as the salesperson. He comments that perhaps firms should spend more on service and less on salespeople. ${ }^{34}$

When rewarding a team, justice perceptions are vital to motivation. It has historically been standard practice to reward team members equally for the achievement of particular objectives. Weinberger $^{35}$ observes that this is not 
perceived as fair and a system is needed to allocate rewards within the account team according to performance. $\mathrm{He}$ suggests an index score of team contributions. The index is a means of capturing feedback from team members - it is a numerical representation of 'team-mate perceptions of support'. This would enable bonuses to be allocated in line with each team members' index scores.

In practice, many team-based rewards are not bonuses, but recognition events or tangible items. Provided there is a short period for qualification, the system is easy to understand and it creates many winners rather than few, this approach can be highly motivating. Certainly, in the early days of key account teams, celebrating small wins and improvements was very successful in supporting a teamwork culture. ${ }^{36}$ As with individual rewards, perceptions of fairness in team rewards can boost loyalty and avoid the costs of staff turnover. It may be resource intensive to design fair systems, but the payback should be worth it. The virtuous circle between employee loyalty, customer loyalty and shareholder loyalty observed by Reichheld and Sasser ${ }^{37}$ might then be achievable. One best-practice company in this regard is the Network and Carrier Services division of telecoms giant BellSouth. The company developed a pay plan for its account managers based on four key elements: individual performance; team performance; customer satisfaction; and strategic actions that built long-term customer relationships. One key account manager described the incentive plan as her 'bible'. ${ }^{38}$ Similarly, Northern Trust Investments (NTI) compensates its sales and investment people on a mix of team and individual performance. NTI also looks at an average of recent performance rather than simply the previous period. ${ }^{39}$

\section{THE PORTFOLIO APPROACH TO REWARDING KEY ACCOUNT MANAGERS}

Fairness within teams is one issue, but what about fairness between teams? A problem in rewarding key account managers is to determine what performance is driven by the skills and abilities of the key account manager or team, and what is driven by the simple fact that some customers are bigger and wealthier than others. One possibility here is the adoption of a portfolio approach.

O'Connell and Marchese ${ }^{40}$ have already recommended a four-stage life-cycle approach to rewarding salespeople. They argue that, in order to retain salespeople and ensure that they have the right opportunities throughout their career, their roles and rewards should be aligned with their career life-cycle stages: as a beginner, taking part in team selling; experienced salespersons on commission; fully-seasoned, multi-year performance; and pre-retirement wind-down.

The O'Connell and Marchese approach recognises that the motivation of money differs by age group. The present authors' approach is fundamentally different in that they anticipate that it is the characteristics of the relationship with the customer which govern what skills are needed from the particular salesperson or key account manager and how he or she should be rewarded, ie the customer's position in the customer portfolio matrix (Figure $\left.1^{41}\right)$. This is more akin to the approach taken by Darmon ${ }^{42}$ which classified sales positions based on the degree of time, relationship management, information handling and complexity. The authors' approach, however, suggests that it is the company's relationship strategy for a customer that should drive how its account managers are paid. 


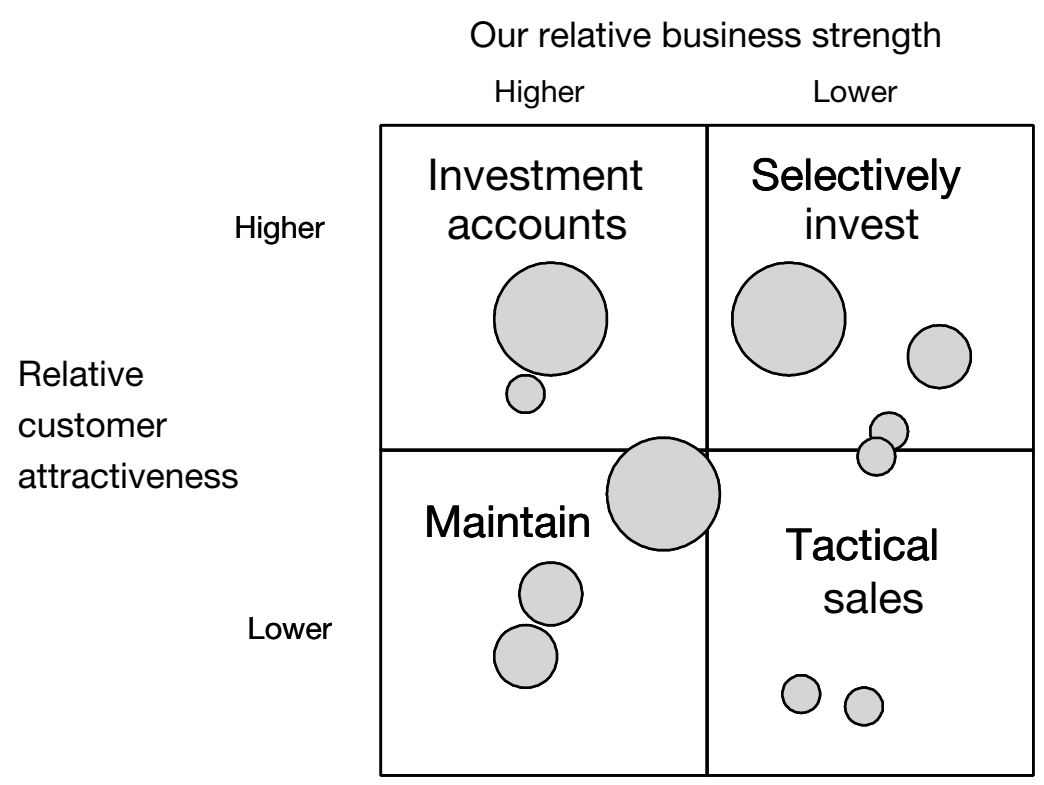

Figure 1 The customer portfolio matrix

In the 'Selectively invest' box, 'missionary selling' is required to acquire or mould new key accounts, and a high degree of personal effort will be needed. A basic salary supplemented by large bonuses based on outcomes over time, but not time dependent, is advocated. Precise outcome measures must be developed to capture the expectations of the company about the relationship outcomes. ${ }^{43}$ In one Fortune 500 company whose salespeople were predominantly focused on new business generation rather than relationship management, bonuses ranged between 3 per cent and 20 per cent of base salary. ${ }^{44}$ Mathworks Inc, the US software company, rewards its account managers in this category with 35 per cent of pay based on commission; by contrast, just 20 per cent of pay for salespeople managing 'Maintain' or 'Tactical sales' type relationships is based on commission. $^{45}$

Investment accounts are more likely to suit a high proportion of salary, 70-80 per cent of on-target earnings, plus bonuses based on achievement of strategic objectives. Often, such accounts are managed on a team basis and compensation must then be based largely on team results. At Hewlett Packard, for example, the top 1,000 accounts are served by teams and the pay of sales managers and executives is largely team-based. ${ }^{46}$

Maintain accounts are suitable for management by non-sales staff.

Salary-only rewards should be considered. Some companies have promoted staff from technical and administrative functions into account management roles where a high level of fixed pay is appropriate. Hewlett Packard has created extended team networks supporting the sales managers; these teams comprise people from research, human resources and technology. ${ }^{47}$

Tactical sales in the low-low box do require traditional selling skills such as opening, objection handling, negotiating and closing. A high level of volume-based commission would be the best approach to achieving returns from 
this category of customers. Sometimes these tactical sales are driven from call centres, to keep selling overheads down. Small but frequent non-financial rewards may also be useful here, as US gas utility Enbridge Gas Distribution has discovered: two or three times a year, Enbridge gives its high-performing salespeople tickets to sporting events or dinner gifts. ${ }^{48}$

\section{CONCLUSION}

The variable pay system can be highly problematic for key account managers. The nature of their engagement with customers is long term, and high levels of variable pay can confuse and demotivate them. This may lead to a negative impact on staff turnover, which is very costly. ${ }^{49}$

Variable pay is a very complex management tool. Rewards convey messages and a crudely designed rewards system can send the wrong messages. At the very least, it might concentrate the salesperson's efforts on picking low-hanging fruit rather than on strategic sales. Increasingly, companies are recognising this; the Alexander Group found that 95 per cent of all companies expect to change their sales compensation plans during 2004 and 22 per cent expect those changes to be major. $^{50}$

It is not easy to design a merit pay system for salespeople and account managers that is consistent, unbiased, accurate, representative and ethical. It may require a special operational team ${ }^{51}$ and involve salespeople in goal setting and process design. ${ }^{52}$ Despite its complexity, however, the most effective way in which a company can achieve its objectives with its most important accounts may be to use a portfolio approach in which the reward system is linked to relationship type. Putting everyone onto the same pay system may be a bad move for a company with key accounts, particularly if that pay system is largely commission-based.

\section{Acknowledgments}

The authors acknowledge the assistance of members of Cranfield's Key Account Management Best Practice Research Club with this research.

\section{References}

1 Weilbaker, D. C. (1999) 'Compensation issues for global account management', The Journal of Selling and Major Account Management, Vol. 2, No. 1, Autumn, pp. 88-95.

2 Cichelli, J. D. (2003) '2004 Sales Compensation Trends Survey', The Alexander Group Inc, Scottsdale, Arizona, USA.

3 O'Connell, B. and Marchese, L. (1995) 'Paying for the relationship, not just the sale', Journal of Compensation and Benefits, Vol. 11, No. 1, July/August.

4 McDonald, M., Millman, A. and Rogers, B. (1995) 'Key account management - Learning from supplier and customer perspectives', Cranfield School of Management research report, Cranfield.

5 Ibid.

6 Puri, S. J. (1992) 'Industrial vendors' selling center: Implications for sales management', Journal of Business and Industrial Marketing, Vol. 7, No. 3, pp. 59-68, Summer.

7 Donaldson, B. (1998) 'The importance of financial incentives in motivating industrial salespeople', The Journal of Selling and Major Account Management, Vol. 1, No. 1, July, pp. 4-16.

8 Cooke, E. F. (1999) 'Control and motivation in sales management through the compensation plan', Journal of Marketing, Winter, pp. 80-83.

9 Donaldson (1998) op. cit.

10 Bartol, K. M. (1999) 'Reframing salesforce compensation systems: An agency theory-based performance management perspective', The Journal of Personal Selling and Sales Management, Vol. 19, No. 3, Summer, pp. 1-16.

11 Oliver, R. L. and Anderson, E. (1994) 'An empirical test of the consequences of behavior- and outcome-based sales control systems', Journal of Marketing, Vol. 58, No. 4, pp. 53-66.

12 Marchetti, M. (1999) 'Compensation is kid stuff', Sales and Marketing Management, Vol. 151, No. 4, pp. 53-59, April.

13 Bartol (1999) op. cit.

14 Harrison, D. A., Virick, M. and William, S. (1996) 'Working without a net: Time, performance, and turnover under maximally contingent rewards', Journal of Applied Psychology, Vol. 81, pp. 331-345.

15 Galea, C. (2004) 'The 2004 compensation survey', Sales and Marketing Management, Vol. 156, No. 6, pp. 28-33, May. 
16 Donaldson (1998) op. cit.

17 Von Bergen, C. W., Soper, B. and Pool, P. W. (2002) 'Competition and goal-based reward systems', The Journal of Selling and Major Account Management, Vol. 4, No. 2, Winter, pp. 33-43.

18 Gundy, P. R. and Gaeta, C. (2004) 'Sales compensation governance: The last frontier of corporate reform', Benefits Quarterly, First Quarter.

19 Tice, T. E. (1997) 'Managing compensation caps in key accounts', The Journal of Personal Selling and Sales Management, Vol. 17, No. 4, pp. 41-47.

20 Gundy and Gaeta (2004) op. cit.

21 Ibid.

22 Tice (1997) op. cit.

23 Bartol (1999) op. cit.

24 Caruth, D. L. and Handlogten-Caruth, G. D. (2002) 'Compensating sales personnel', The American Salesman, April, pp. 6-15.

25 Cooke (1999) op. cit.

26 Eisenhardt, K. M. (1988) 'Agency- and institutional-theory explanations: The case of retail sales compensation', Academy of Management Journal, Vol. 31, pp. 488-511.

27 Galea (2004) op. cit.

28 Weilbaker (1999) op. cit.

29 Kalwani, M. U. and Narayandas, N. (1995) 'Long-term manufacturer-supplier relationships: Do they pay off for supplier firms?', Journal of Marketing, Vol. 59, No. 1, pp. 1-16. January.

30 Wotruba, T. R. and Pulsifer, J. L. (2000) 'The use and effectiveness of profit-oriented quotas for salespeople in achieving company objectives', The Journal of Selling and Major Account Management, Vol. 2, No. 4, Summer, pp. 38-49.

31 O'Connell and Marchese (1995) op. cit.

32 Weilbaker (1999) op. cit.

33 Bartol (1999) op. cit.

34 Sharma, A. (2000) 'Do salespeople and customers understand each other? Surprising results from extant research', Journal of Selling and Major Account Management, Autumn, Vol. 3, No. 1, pp. 29-39.

35 Weinberger, T. E. (1998) 'A method for determining the equitable allocation of team-based pay:

Rewarding members of a cross-functional account team', Compensation and Benefits Management, Autumn, Vol. 14, No. 4, pp. 18-27.

36 McDonald, Millman and Rogers (1995) op. cit. 37 Reichheld, F. F. and Sasser Jr, W. E. (1990) 'Zero defections: Quality comes to services', Harvard Business Review, Vol. 68, No. 5, pp. 105-111. Sept-Oct.

38 Marchetti (1999) op. cit.

39 Mahmud, S. (2004) 'Northern Trust alters compensation rules for staff, Pensions \& Investments, Vol. 32, No. 15, pp. 13-14.

40 O'Connell and Marchese (1995) op. cit.

41 Source: Fiocca, R. (1982) 'Account portfolio analysis for strategy development', Industrial Marketing Management, Vol. 11, No. 1, pp. 53-62; amended by McDonald, Millman and Rogers (1995) op cit.

42 Darmon, R. Y. (1998) 'A conceptual scheme and procedure for classifying sales positions', Journal of Personal Selling and Sales Management, Vol. 18 (Winter), pp. 31-46.

43 Bartol (1999) op. cit.

44 Ramaswami, S. N. and Singh, J. (2003) 'Antecedents and consequences of merit pay fairness for industrial salespeople', Journal of Marketing, October, Vol. 67, pp. $46-66$.

45 Marchetti (1999) op. cit.

46 Hawes, P. (2002) 'Hewlett Packard builds a one-to-one culture', 1 to 1 Magazine, May.

47 Hawes (2002) op. cit.

48 Galea (2004) op. cit.

49 Bartol (1999) op. cit.

50 Galea (2004) op. cit.

51 Gundy and Gaeta (2004) op. cit.

52 Ramaswami and Singh (2003) op. cit. 